\title{
Economic and Fast-track Rehabilitation of Concrete Pavements and Bridge Decks
}

\author{
Chris Ramseyer, ${ }^{1)}$ Brent Chancellor, ${ }^{1)}$ and Thomas H.-K. Kang ${ }^{2)}$
}

(Received June 23, 2008, Revised November 30, 2008, Accepted November 30, 2008)

\begin{abstract}
The last 10 years have seen considerable growth in the use of proprietary and special repair cements for concrete pavements in the state of Oklahoma. Many of these products lend themselves to "fast track" construction techniques that allow reopening to traffic within 12 hours or less. These products achieve high early strengths by accelerating the Portland cement hydration process for both Type I and Type III cements. In this paper, the important features of a durable repair which include strength, compatibility and bond or adhesion are first discussed. Then the development, testing and field implementation of the aforementioned materials are discussed including the learning curve required to implement a repair system, not just install a new material. Some of the materials discussed, while expensive on a cost per unit basis, hold great promise for economical use on fast track project.
\end{abstract}

Keywords : rehabilitation, concrete pavements, very early strength, drying shrinkage, workability

\section{Introduction}

The time required for a concrete mixture to achieve a minimum compressive strength influences the timing of opening a repaired road to service. Zia et al. ${ }^{1}$ applied a criterion for minimum compressive strength of $13.8 \mathrm{MPa}(2,000 \mathrm{psi})$ in six hours for Very Early Strength (VES) High Performance Concrete. This criterion was used by the Oklahoma Department of Transportation (ODOT) in a 1997 contract to repair and patch the deck on the I-40 CrossTown Bridge in Oklahoma City. Since the I-40 Cross-Town Bridge is one of the most heavily traveled sections of road in the U.S.A. with over 120,000 vehicles per day, a six-hour opening was critical to success. However, the concrete that was produced at the job site was unable to meet this criterion consistently. ODOT initiated this research to find an improved concrete mix design that would also meet the desire for increased durability.

The interaction of a patch to the existing pavement is a complex problem. Throughout the literature, ${ }^{2-4}$ the durability of concrete patches is linked to the compatibility between the patch material and the substrate. Compatibility is affected by many factors which include (1) chemical and electrochemical differences, (2) permeability, (3) dimensional compatibility, and (4) drying shrinkage, as well as (5) thermal expansion, (6) creep, (7) modulus of elasticity, and (8) patch geometry. Of these compatibility factors, drying shrinkage is one of the most important factors that influence the durability of

\footnotetext{
${ }^{1}$ School of Civil Engineering and Environmental Science, Univ. of Oklahoma, Norman, OK 73019, USA.

2) KCI Member, School of Civil Engineering and Environmental Science, Univ. of Oklahoma, Norman, OK 73019, USA. E-mail: tkang@ou.edu

Copyright (c) 2008, Korea Concrete Institute. All rights reserved, including the making of copies without the written permission of the copyright proprietors.
}

a patch. On the I-40 cross-town bridge project, drying shrinkage cracks occurred on some of the patches in less than one week.

Because the existing concrete substrate has already progressed to its stable drying volume, any shrinkage of the repair materials should be considered "differential shrinkage." When shrinkage of the concrete patch occurs, tensile stresses are created in the patch material, compressive stresses are created in the concrete substrate, and shear stresses develop at the bond interface. If the tensile stresses caused by the restrained shrinkage exceed the tensile capacity of the patch material, the patch material will crack.

Drying shrinkage is caused by several possible material characteristics. These include capillary stress, disjoining pressure and surface tension. ${ }^{5}$ The recently developed shrinkage-reducing admixtures (SRA's) decrease drying shrinkage by decreasing capillary stress. Unfortunately, the admixtures also affect the concrete by retarding the mix and reducing the heat generated by hydration; ${ }^{6}$ characteristics that would work against the success of patching materials. Decreasing the amount of cement per unit volume would decrease the amount of C-S-H (Calcium-Silicate-Hydrate) that would be available for disjoining pressure to affect.

High-Range Water Reducers (HRWR's) are used to improve workability at low water-to-cement (w/c) ratio but unfortunately, HRWR's also retard the concrete mix. ${ }^{7}$ One commercial HRWR product (ADVA), which was reported (by the manufacturer) not to retard the mix, was chosen for this study.

The purpose of the work reported in this paper was to develop a concrete mixture that would be suitable for patching rigid concrete pavements and concrete bridge decks. Therefore, the combined effect of accelerators, superplasticizer and cement content on the shrinkage and strength characteristics of very early strength Portland cement concrete was investigated. 


\section{Test program - type III portland cement}

\subsection{Experimental program}

This portion of the study consisted of three sets of experiments. In the first set, the admixtures were held constant; however, the cement content and the water-to-cement (w/c) ratio varied. In the second set of concrete mixtures, the amounts of accelerator and superplasticizer varied independently, and the cement content and the w/c ratio were held constant. In the third set of mixtures, an air entraining agent was added to mix design.

Tables 1, 2, and 3 report mixture proportions for Sets 1, 2, and 3, respectively. Sample nomenclature indicates the Set number followed by a letter (A, B, C etc.) designation of the mix. Two waterto-cement ratios (0.35 and 0.40) and two cement contents (297 and $356 \mathrm{~kg} / \mathrm{m}^{3}$ ) were evaluated in Set 1 , while maintaining a constant ratio of accelerator $(83.45 \mathrm{ml} / \mathrm{kg})$ and HRWR $(9.78 \mathrm{ml} / \mathrm{kg})$. Set 2 contained mixes with variations in the amount of accelerator ( 0 to $111.3 \mathrm{ml} / \mathrm{kg}$ ) while maintaining a constant cement (356 kg/ $\left.\mathrm{m}^{3}\right)$ and HRWR $(9.78 \mathrm{ml} / \mathrm{kg}$ ) and a constant $\mathrm{w} / \mathrm{c}$ ratio $(0.35)$. Set 3 is the final mix design with the inclusion of an air entrainment agent.

The mix proportions were designed using the Absolute Volume method. In this method, variations in cement and/or the w/c ratio are "made up" for with variations in the quantity of fine aggregate. Due to the large volume that the DCI (accelerator) represents, the non-water volume of this admixture was accounted for in proportioning the mix.
Table 3 Mixture proportions for Group 3 (final mix design)

\begin{tabular}{c|c|c}
\hline \multicolumn{2}{|c|}{} & $3-\mathrm{A}$ \\
\hline \hline Cement & $\mathrm{kg} / \mathrm{m}^{3}\left(\mathrm{lbs} / \mathrm{yd}^{3}\right)$ & $356(600)$ \\
\hline Water & $\mathrm{kg} / \mathrm{m}^{3}\left(\mathrm{lbs} / \mathrm{yd}^{3}\right)$ & $125(210)$ \\
\hline Fine aggregates & $\mathrm{kg} / \mathrm{m}^{3}\left(\mathrm{lbs} / \mathrm{yd}^{3}\right)$ & $837(1411)$ \\
\hline Coarse aggregates & $\mathrm{kg} / \mathrm{m}^{3}\left(\mathrm{lbs} / \mathrm{yd}^{3}\right)$ & $1052(1773)$ \\
\hline HRWR $($ ADVA) & $\mathrm{ml} / \mathrm{m}^{3}\left(\mathrm{oz} / \mathrm{yd}^{3}\right)$ & $3481(90)$ \\
\hline Accelerator $(\mathrm{DCI})$ & $\mathrm{L} / \mathrm{m}^{3}\left(\mathrm{oz} / \mathrm{yd}^{3}\right)$ & $29.71(768)$ \\
\hline AEA (Daravair-1000) & $\mathrm{ml} / \mathrm{m}^{3}\left(\mathrm{oz} / \mathrm{yd}^{3}\right)$ & $1741(45)$ \\
\hline w/c ratio & & 0.35 \\
\hline HRWR/ cement & $\mathrm{ml} / \mathrm{kg}(\mathrm{oz} / \mathrm{cwt})$ & $9.78(15)$ \\
\hline Accelerator / cement & $\mathrm{ml} / \mathrm{kg}(\mathrm{oz} / \mathrm{cwt})$ & $83.45(128)$ \\
\hline
\end{tabular}

Fine aggregate (Oklahoma Dover Sand) conformed to ASTM $\mathrm{C} 33^{8}$ with a fineness modulus of 2.5. The coarse aggregate (Oklahoma Richard Spur Limestone) also conformed to ASTM C $33^{8}$ with a dry rodded unit weight of $1,618 \mathrm{~kg} / \mathrm{m}^{3}\left(101 \mathrm{lbs} / \mathrm{ft}^{3}\right)$, and a \#67 gradation. Type III Portland cement was used in all mixtures. The accelerator conforms to ASTM C $494^{9}$ as a Type C admixture while the superplasticizer conforms to ASTM C $494^{9}$ as a Type F. The air entrainment agent conforms to ASTM C $260 .^{10}$

Materials were mixed in a $0.17 \mathrm{~m}^{3}\left(6 \mathrm{ft}^{3}\right)$ drum mixer in the laboratory. The initial concrete temperature of the batches was nearly equal as reported in Table 4. Immediately after the specimens

Table 1 Mixture properties for the patches on the I-40 cross-town bridge and for Group 1

\begin{tabular}{c|c|c|c|c|c}
\hline \multicolumn{2}{c|}{} & $\mathrm{I}-40$ & $1-\mathrm{A}$ & $1-\mathrm{B}$ & $1-\mathrm{C}$ \\
\hline \hline Cement & $\mathrm{kg} / \mathrm{m}^{3}\left(\mathrm{lbs} / \mathrm{yd}^{3}\right)$ & $468(820)$ & $356(600)$ & $356(600)$ & $297(500)$ \\
\hline Water & $\mathrm{kg} / \mathrm{m}^{3}\left(\mathrm{lbs} / \mathrm{yd}^{3}\right)$ & $178(300)$ & $125(210)$ & $142(240)$ & $119(200)$ \\
\hline Fine aggregates & $\mathrm{kg} / \mathrm{m}^{3}\left(\mathrm{lbs} / \mathrm{yd}^{3}\right)$ & $603(1017)$ & $838(1412)$ & $791(1333)$ & $915(1543)$ \\
\hline Coarse aggregates & $\mathrm{kg} / \mathrm{m}^{3}\left(\mathrm{lbs} / \mathrm{yd}^{3}\right)$ & $1068(1800)$ & $1052(1773)$ & $1052(1773)$ & $1052(1773)$ \\
\hline HRWR (ADVA) & $\mathrm{ml} / \mathrm{m}^{3}\left(\mathrm{oz} / \mathrm{yd}^{3}\right)$ & $0(0)$ & $3481(90)$ & $3481(90)$ & $2091(75)$ \\
\hline HRWR (Sikament $10 \mathrm{ESL})$ & $\mathrm{ml} / \mathrm{m}^{3}\left(\mathrm{oz} / \mathrm{yd}^{3}\right)$ & $2553(66)$ & $0(0)$ & $0(0)$ & $0(0)$ \\
\hline Accelerator $(\mathrm{DCI})$ & $\mathrm{L} / \mathrm{m}^{3}\left(\mathrm{oz} / \mathrm{yd}^{3}\right)$ & $0(0)$ & $29.71(768)$ & $29.71(768)$ & $24.76(640)$ \\
\hline Accelerator $($ Sika Rapid) & $\left.\mathrm{L} / \mathrm{m}^{3}(\mathrm{oz} / \mathrm{yd})^{3}\right)$ & $12.69(328)$ & $0(0)$ & $0(0)$ & $0(0)$ \\
\hline AEA (Sika AER) & $\left.\mathrm{ml} / \mathrm{m}^{3}(\mathrm{oz} / \mathrm{yd})^{3}\right)$ & $1741(45)$ & $0(0)$ & $0(0)$ & $0(0)$ \\
\hline W/c ratio & & 0.37 & 0.35 & 9.40 & 0.40 \\
\hline HRWR / cement & $\mathrm{ml} / \mathrm{kg}(\mathrm{oz} / \mathrm{cwt})$ & $5(8)$ & $9.78(15)$ & $9.78(15)$ & $9.78(15)$ \\
\hline Accelerator / cement & $\mathrm{ml} / \mathrm{kg}(\mathrm{oz} / \mathrm{cwt})$ & $26.08(40)$ & $83.45(128)$ & $83.45(128)$ & $83.45(128)$ \\
\hline
\end{tabular}

Table 2 Mixture proportions for Group 2 (variation in admixtures)

\begin{tabular}{c|c|c|c|c|c|c}
\hline \multicolumn{2}{c}{} & $2-\mathrm{A}$ & $2-\mathrm{B}$ & $2-\mathrm{C}$ & $2-\mathrm{D}$ & $2-\mathrm{E}$ \\
\hline \hline Cement & $\mathrm{kg} / \mathrm{m}^{3}\left(\mathrm{lbs} / \mathrm{yd}^{3}\right)$ & $356(600)$ & $356(600)$ & $356(600)$ & $356(600)$ & $356(600)$ \\
\hline Water & $\mathrm{kg} / \mathrm{m}^{3}\left(\mathrm{lbs} / \mathrm{yd}^{3}\right)$ & $125(210)$ & $125(210)$ & $125(210)$ & $125(210)$ & $125(210)$ \\
\hline Fine aggregates & $\mathrm{kg} / \mathrm{m}^{3}\left(\mathrm{lbs} / \mathrm{yd}^{3}\right)$ & $915(1543)$ & $889(1499)$ & $863(1455)$ & $837(1411)$ & $812(1368)$ \\
\hline Coarse aggregates & $\mathrm{kg} / \mathrm{m}^{3}\left(\mathrm{lbs} / \mathrm{yd}^{3}\right)$ & $1052(1773)$ & $1052(1773)$ & $1052(1773)$ & $1052(1773)$ & $1052(1773)$ \\
\hline HRWR $($ ADVA) & $\mathrm{ml} / \mathrm{m}^{3}\left(\mathrm{oz}_{\mathrm{yd}}{ }^{3}\right)$ & $3481(90)$ & $3481(90)$ & $3481(90)$ & $3481(90)$ & $3481(90)$ \\
\hline Accelerator $(\mathrm{DCI})$ & $\mathrm{L} / \mathrm{m}^{3}\left(\mathrm{oz} / \mathrm{yd}^{3}\right)$ & $0(0)$ & $9.90(256)$ & $19.80(512)$ & $29.71(768)$ & $39.61(1024)$ \\
\hline W/c ratio & & 0.35 & 0.35 & 0.35 & 0.35 & 0.35 \\
\hline HRWR/ cement & $\mathrm{ml} / \mathrm{kg}(\mathrm{oz} / \mathrm{cwt})$ & $9.78(15)$ & $9.78(15)$ & $9.78(15)$ & $9.78(15)$ & $9.78(15)$ \\
\hline Accelerator/ cement & $\mathrm{ml} / \mathrm{kg}(\mathrm{oz} / \mathrm{cwt})$ & $0(0)$ & $27.82(43)$ & $55.64(85)$ & $83.45(128)$ & $111.30(171)$ \\
\hline
\end{tabular}


Table 4 Test results of fresh and hardened properties (with Type III Portland cement).

\begin{tabular}{|c|c|c|c|c|c|c|c|c|c|c|c|c|}
\hline & & $\mathrm{I}-40$ & $1-\mathrm{A}$ & $1-B$ & $1-\mathrm{C}$ & $2-\mathrm{A}$ & $2-\mathrm{B}$ & $2-\mathrm{C}$ & $2-\mathrm{D}$ & $2-\mathrm{E}$ & $2-\mathrm{F}$ & $3-\mathrm{A}$ \\
\hline Slump & $\begin{array}{l}\mathrm{mm}) \\
\text { (in.) }\end{array}$ & $\begin{array}{c}25 \\
(1.00)\end{array}$ & $\begin{array}{c}64 \\
(2.50)\end{array}$ & $\begin{array}{c}178 \\
(7.00)\end{array}$ & $\begin{array}{c}44 \\
(1.75)\end{array}$ & $\begin{array}{c}25 \\
(1.00)\end{array}$ & $\begin{array}{c}32 \\
(1.25)\end{array}$ & $\begin{array}{c}32 \\
(1.25)\end{array}$ & $\begin{array}{c}64 \\
(2.50)\end{array}$ & $\begin{array}{c}64 \\
(2.50)\end{array}$ & $\begin{array}{c}178 \\
(7.00)\end{array}$ & $\begin{array}{c}38 \\
(1.50)\end{array}$ \\
\hline Unit weight & $\begin{array}{c}\left(\mathrm{kg} / \mathrm{m}^{3}\right) \\
\left(\mathrm{lb} / \mathrm{ft}^{3}\right)\end{array}$ & N.A. & $\begin{array}{c}2433 \\
(151.9)\end{array}$ & $\begin{array}{c}2440 \\
(152.3)\end{array}$ & $\begin{array}{c}2401 \\
(149.9)\end{array}$ & $\begin{array}{c}2433 \\
(151.9)\end{array}$ & $\begin{array}{c}2437 \\
(152.1)\end{array}$ & $\begin{array}{c}2441 \\
(152.4)\end{array}$ & $\begin{array}{c}2433 \\
(151.9)\end{array}$ & $\begin{array}{c}2438 \\
(152.2)\end{array}$ & $\begin{array}{c}2440 \\
(152.3)\end{array}$ & $\begin{array}{c}2376 \\
(148.4)\end{array}$ \\
\hline Batch temperature & $\begin{array}{l}\text { (C) } \\
(\mathrm{F})\end{array}$ & $\begin{array}{c}29.4 \\
(85.0)\end{array}$ & $\begin{array}{c}26.6 \\
(80.0)\end{array}$ & $\begin{array}{c}27.7 \\
(82.0)\end{array}$ & $\begin{array}{c}24.4 \\
(76.0)\end{array}$ & $\begin{array}{c}25.8 \\
(78.5)\end{array}$ & $\begin{array}{c}26.6 \\
(80.0)\end{array}$ & $\begin{array}{c}27.2 \\
(81.0)\end{array}$ & $\begin{array}{c}26.6 \\
(80.0)\end{array}$ & $\begin{array}{c}27.7 \\
(82.0)\end{array}$ & $\begin{array}{c}27.7 \\
(82.0)\end{array}$ & $\begin{array}{c}28.3 \\
(83.0)\end{array}$ \\
\hline Air content & $(\%)$ & 3.1 & 2.3 & 2.2 & 2.6 & 2.8 & 2.4 & 2.1 & 2.3 & 2.2 & 2.0 & 5.4 \\
\hline $\begin{array}{l}\text { Compressive strength } \\
\text { at } 6 \text { hours }\end{array}$ & $\begin{array}{c}(\mathrm{MPa}) \\
\text { (psi) }\end{array}$ & $\begin{array}{l}12.83 \\
(1860)\end{array}$ & $\begin{array}{c}30.21 \\
(4380)\end{array}$ & $\begin{array}{l}23.31 \\
(3380)\end{array}$ & $\begin{array}{l}20.83 \\
(3020)\end{array}$ & $\begin{array}{l}0.34 \\
(50)\end{array}$ & $\begin{array}{l}12.21 \\
(1770)\end{array}$ & $\begin{array}{l}24.34 \\
(3530)\end{array}$ & $\begin{array}{c}30.21 \\
(4380)\end{array}$ & $\begin{array}{l}36.55 \\
(5300)\end{array}$ & $\begin{array}{l}22.76 \\
(3300)\end{array}$ & $\begin{array}{l}21.45 \\
(3110)\end{array}$ \\
\hline $\begin{array}{c}\text { Compressive strength } \\
\text { at } 1 \text { day }\end{array}$ & $\begin{array}{c}(\mathrm{MPa}) \\
(\mathrm{psi})\end{array}$ & $\begin{array}{l}24.62 \\
(3570)\end{array}$ & $\begin{array}{l}56.00 \\
(8120)\end{array}$ & $\begin{array}{l}46.21 \\
(6700)\end{array}$ & $\begin{array}{l}43.31 \\
(6280)\end{array}$ & $\begin{array}{l}42.55 \\
(6170)\end{array}$ & $\begin{array}{l}49.59 \\
(7190)\end{array}$ & $\begin{array}{l}49.66 \\
(7200)\end{array}$ & $\begin{array}{l}56.00 \\
(8120)\end{array}$ & $\begin{array}{c}57.31 \\
(8310)\end{array}$ & $\begin{array}{l}46.14 \\
(6690)\end{array}$ & $\begin{array}{c}40.00 \\
(5800)\end{array}$ \\
\hline $\begin{array}{c}\text { Compressive strength } \\
\text { at } 28 \text { days }\end{array}$ & $\begin{array}{c}(\mathrm{MPa}) \\
(\mathrm{psi})\end{array}$ & $\begin{array}{l}28.55 \\
(4140)\end{array}$ & $\begin{array}{c}74.69 \\
(10830)\end{array}$ & $\begin{array}{c}70.90 \\
(10280)\end{array}$ & $\begin{array}{c}66.69 \\
(9670)\end{array}$ & $\begin{array}{c}64.69 \\
(9380)\end{array}$ & $\begin{array}{l}68.21 \\
(9890)\end{array}$ & $\begin{array}{c}69.38 \\
(10060)\end{array}$ & $\begin{array}{c}74.69 \\
(10830)\end{array}$ & $\begin{array}{c}78.97 \\
(11450)\end{array}$ & $\begin{array}{c}70.41 \\
(10210)\end{array}$ & $\begin{array}{c}62.07 \\
(9000)\end{array}$ \\
\hline Shrinkage at 28 days & $(\mathrm{m} / \mathrm{m})$ & 740 & 273 & 413 & 343 & 220 & 257 & 253 & 273 & 300 & 270 & 280 \\
\hline Concrete temperature & $\begin{array}{l}\text { (C) } \\
\text { (F) }\end{array}$ & $\begin{array}{c}42.2 \\
(108)\end{array}$ & $\begin{array}{c}37.7 \\
(100)\end{array}$ & $\begin{array}{c}38.3 \\
(101)\end{array}$ & $\begin{array}{l}34.4 \\
(94)\end{array}$ & $\begin{array}{l}27.7 \\
(82)\end{array}$ & $\begin{array}{l}33.3 \\
(92)\end{array}$ & $\begin{array}{l}36.6 \\
(98)\end{array}$ & $\begin{array}{c}37.7 \\
(100)\end{array}$ & $\begin{array}{l}40.0 \\
(104)\end{array}$ & $\begin{array}{l}40.0 \\
(104)\end{array}$ & $\begin{array}{l}40.0 \\
(104)\end{array}$ \\
\hline \multicolumn{13}{|c|}{ Mix 3-A Additional Properties } \\
\hline Modulus of elasticity & $\begin{array}{c}\text { (MPa) } \\
(\mathrm{ksi})\end{array}$ & $\begin{array}{l}36400 \\
(5289)\end{array}$ & $\begin{array}{c}\text { Slant } \\
\text { Shear at } 1 \\
\text { day }\end{array}$ & $\begin{array}{c}(\mathrm{MPa}) \\
(\mathrm{psi})\end{array}$ & $\begin{array}{c}10.55 \\
(1530)\end{array}$ & \begin{tabular}{|c|} 
Rapid \\
Chloride \\
Ion Per- \\
meability
\end{tabular} & $\begin{array}{l}1487 \\
\text { (Low) }\end{array}$ & $\begin{array}{c}\text { Initial Set } \\
\text { Time }\end{array}$ & $57 \mathrm{~min}$ & $\begin{array}{c}\text { Final Set } \\
\text { Time }\end{array}$ & $83 \mathrm{~min}$ & \\
\hline
\end{tabular}

were cast, they were placed in an environmental chamber at $23^{\circ} \mathrm{C}$ $\left(73.4^{\circ} \mathrm{F}\right)$ and $50 \%$ humidity. The specimens were grouped close to each other and covered on their tops and sides with insulating blankets identical to the curing blankets used in the Oklahoma City I-40 Cross-Town Bridge project. A cylinder with a thermocouple connected to a chart recorder was placed in the middle of each group of specimens to monitor the heat of hydration. At six hours, the insulating blanket was removed from the cylinders. The cylinders were then dry cured in the environmental chamber at $23^{\circ} \mathrm{C}\left(73.4^{\circ} \mathrm{F}\right)$ and $50 \%$ humidity. This method of curing accurately models the behavior of a patch in a bridge deck to within $\pm 1.5^{\circ} \mathrm{C}\left(2.5^{\circ} \mathrm{F}\right)$. The insulation blanket effectively reduces the loss of heat from the samples, and improves the strength of mix designs that can generate higher heats of hydration by allowing the mix to in effect generate its own "heat curing."

At six hours, the length change prisms were removed and tested in conformance with ASTM C $490 .{ }^{11}$ The measurement at 6 hours initialized the length change data which were subsequently collected at 9 hours, 12 hours, 1 day, 3 days, 7 days, 28 and 365 days. Concrete compressive strengths were measured in conformance with ASTM C $39 .{ }^{12}$ Compressive strength was measured at 4 hours, 6 hours, 9 hours, 12 hours, 1 day, 3 days, 7 days, and 28 days.

Once a final mix design was chosen, it was further tested to better understand its properties. These tests included ASTM C $882^{13}$ to test bond strength by slant shear, ASTM C $469^{14}$ to determine the static Modulus of Elasticity, ASTM C $1202^{15}$ to determine resistance to chloride ion penetration, and ASTM C $403^{16}$ to determine each mix's time to setting. These test results are included in Table 4. For slump, testing, $0.07 \mathrm{~m}^{3}\left(2.5 \mathrm{ft}^{3}\right)$ of concrete was made, half of the batch was placed in a wheel barrel and left undisturbed, and the other half was kept agitated in the mixer. Slump tests were performed alternately on each. The data from these tests, which can be found in Fig. 1 show how mechanical energy (i.e. vibration) may change the concrete's fresh properties (e.g.,

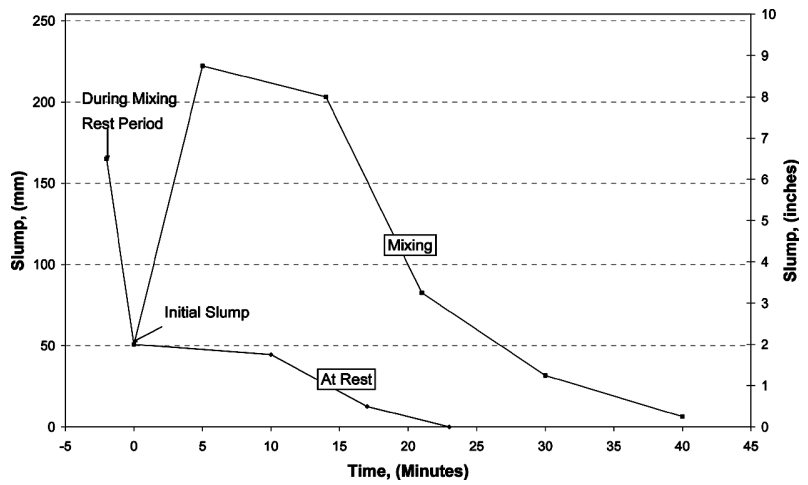

Fig. 1 Slump loss with time (Mix 3-A).

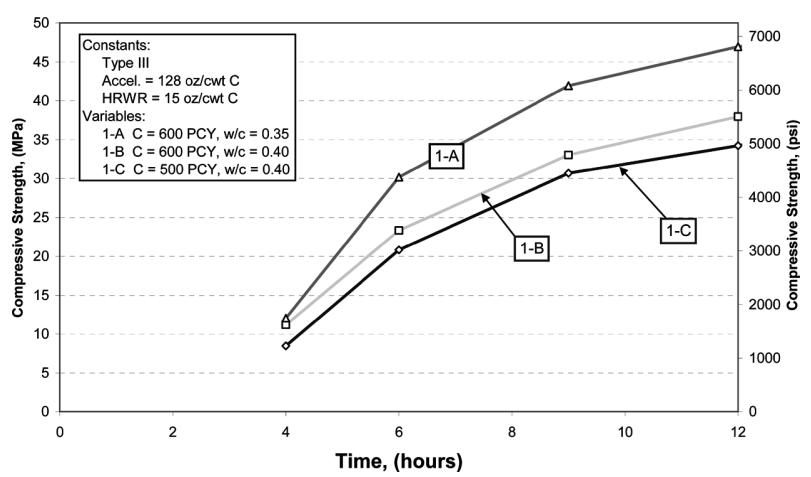

Fig. 2 Early age compressive strength gain (Set 1 mixtures).

increase in workability).

\subsection{Testing and discussion of test results}

Table 4 presents test results of the fresh and hardened properties. The compressive strength and shrinkage results are an average of three cylinders or prisms. Table 4 also lists the results that further 
define the final mix design characteristics.

Figure 2 illustrates the compressive strength of the first set of mixtures with varying cement content and water-to-cement $(\mathrm{w} / \mathrm{c})$ ratio. It illustrates the compressive strength over time between four hours and one day, the time frame of most interest for patching. As expected, the mix with the lowest $\mathrm{w} / \mathrm{c}$ ratio and sufficient cement in Set 1 had a significantly higher compressive strength at an early age. What was unexpected was a compressive strength of $31 \mathrm{MPa}$ (4,500 psi) at six hours for Mix 1-A. This was the initial indication that a Very Early Strength (VES) Concrete with a low cement content was possible. At 28 days, the compressive strengths of all three of these mixes were within $3.5 \mathrm{MPa}$ ( $500 \mathrm{psi}$ ) of each other. Figure 3 illustrates the shrinkage of the first set of mixtures. Also, as expected, the mix with the lowest w/c ratio in Set 1, had the overall lowest shrinkage. The shrinkage results for Set 1 also indicate a corresponding decrease in shrinkage with a decrease in cement content.

Figure 4 illustrates the compressive strength of the portion of the second set of mixtures in which the accelerator was the variable. In general, these mixes were easy to finish and had an acceptable workability which amounted to an improvement over the original I-40 ODOT mix. However, patch mixes were stiffer than standard concrete; hence the rating was only "acceptable." The mixture with the maximum accelerator (Mix 2-E) did tend to be a bit sticky, but was still workable.

The results for Set 2's compressive strengths (Fig. 4) were as expected. The mix design with the most accelerator gained strength fastest. What was unexpected was the increase in compressive strength between Mixes 2-A and 2-B. The addition of a

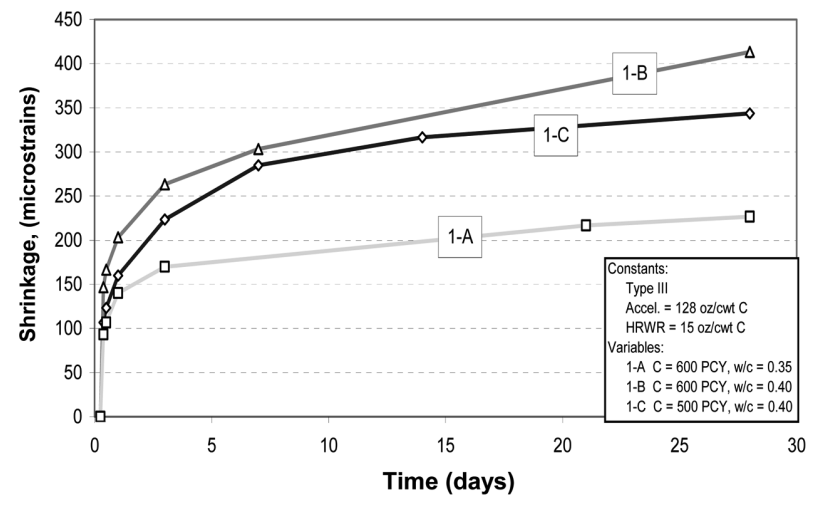

Fig. 3 Shrinkage (Set 1 mixtures).

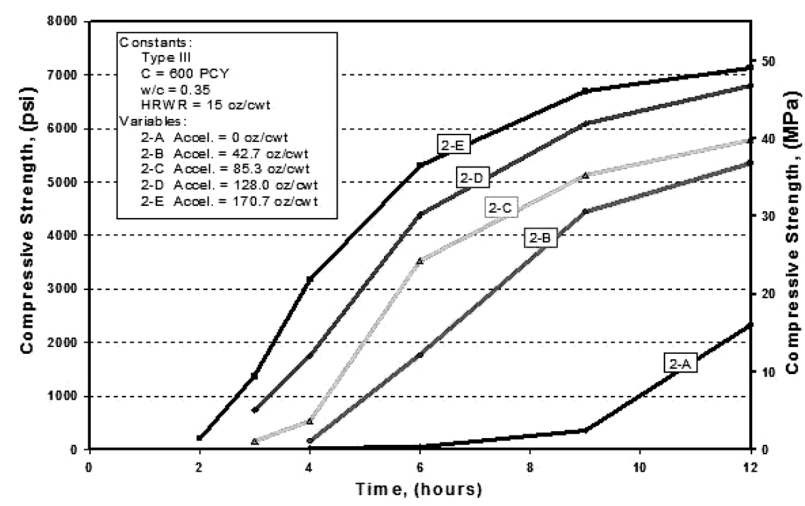

Fig. 4 Early age compressive strength gain (Set 2 mixtures).

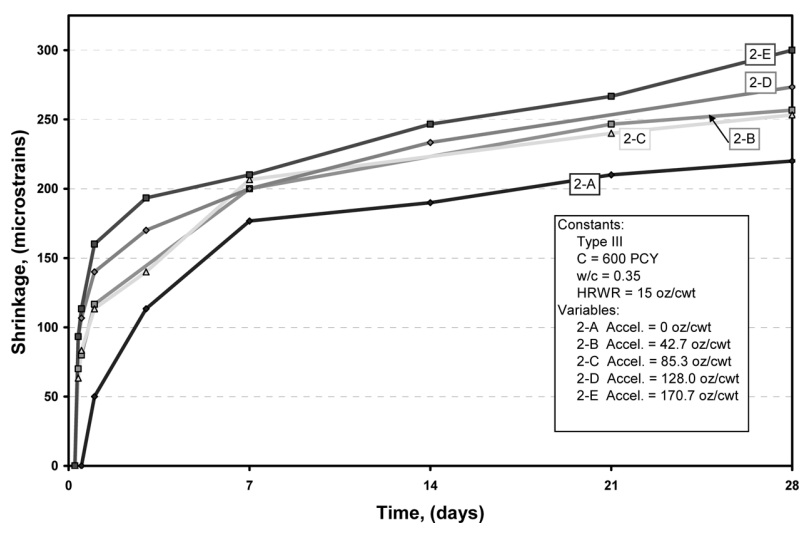

Fig. 5 Shrinkage (Set 2 mixtures).

small amount of accelerator, only $28.04 \mathrm{ml} / \mathrm{kg}$ (43 oz/cwt) of cement increased the compressive strength to $27.6 \mathrm{MPa}$ (4000 psi) at nine hours. At 28 days, the relative strength order of the mixes had not changed. The mix with the most accelerator was still the strongest, and the mix without any accelerator was still the weakest. However, while the order of strength was still intact, the strengths at 28 days were tightly clustered between 79.3 and 63.8 $\mathrm{MPa}(11,500$ and 9,250 psi).

Figure 5 illustrates the shrinkage results for this portion of the second set of mixtures. Note that the mixture with no accelerator

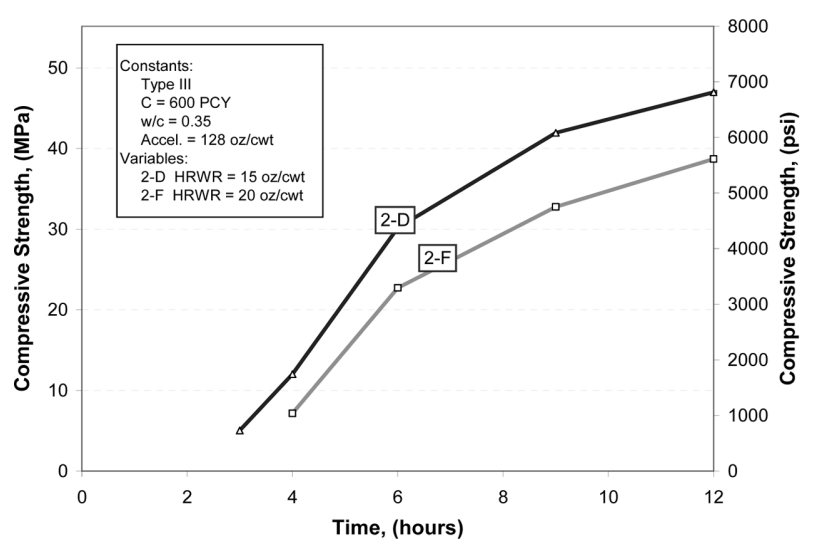

Fig. 6 Early age compressive strength gain (Mix 2-D and 2-F).

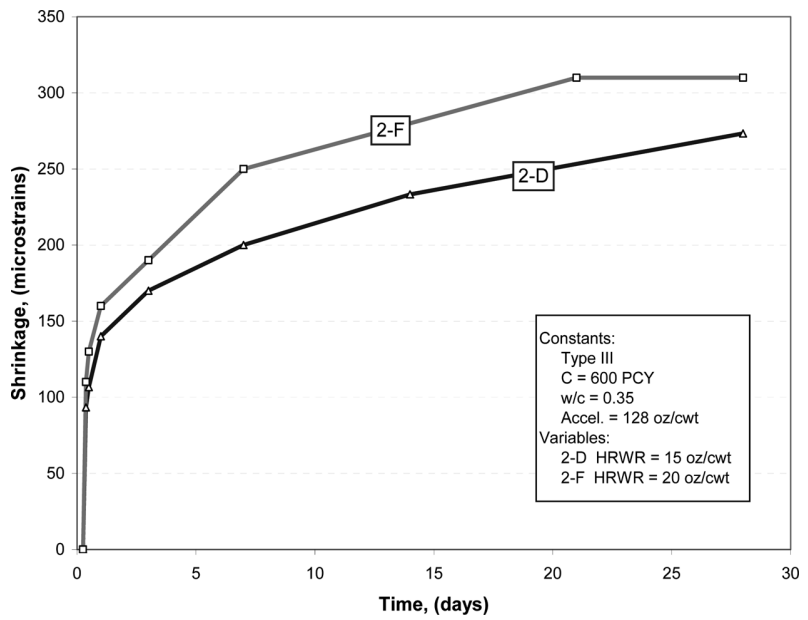

Fig. 7 Shrinkage (Mix 2-D and 2-F). 
(Mix 2-A) was initialized at 1 day and not 6 hours. This makes this mixture register approximately 125 microstrains lower than the other mixtures.

The statement the investigators had been led to believe, namely, that the HRWR had minimal set retarding features was tested next. Figures 6 and 7 illustrate the portion of the second set of mixtures in which the HRWR was the variable. Unexpectedly, Mix 2-D was retarded by almost $25 \%$ of its compressive strength at six hours when the HRWR was increased to $13.04 \mathrm{ml} / \mathrm{kg}$ (20 oz/cwt). This underscored out the necessity of maintaining the HRWR at $9.78 \mathrm{ml} / \mathrm{kg}$ (15 oz/cwt). At this dosage rate, the concrete has a slump of $650 \mathrm{~mm}$ (2.5 in.), which barely meets ODOT's requirements.

With the knowledge that the addition of AEA decreases compressive strength, Mix 2-D was selected as the basis for the final Set 3. Figure 8 compares the compressive strength of the final mix design to the mix design used by ODOT on the I-40 bridge repair project. Compared to the I-40 ODOT Mix, Mix 3-A (final mix) had $33 \%$ more compressive strength at six hours, despite having $2 \%$ more entrained air in the mix. This strength gain may be a function of the increased speed with which the DCI accelerator generates heat of hydration versus the Sika Rapid. This can be seen in Fig. 9, which compares the temperatures of the curing concrete from these two mix designs. With the DCI accelerator, stage 2 existed in the rate of heat evolution as described by Mindess et al. ${ }^{5}$

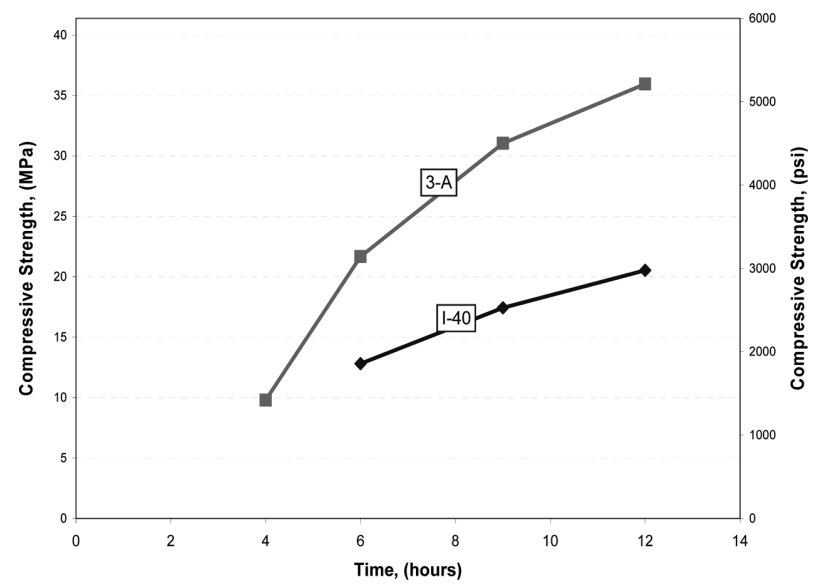

Fig. 8 Early age compressive strength gain (Mix 3-A and I-40).

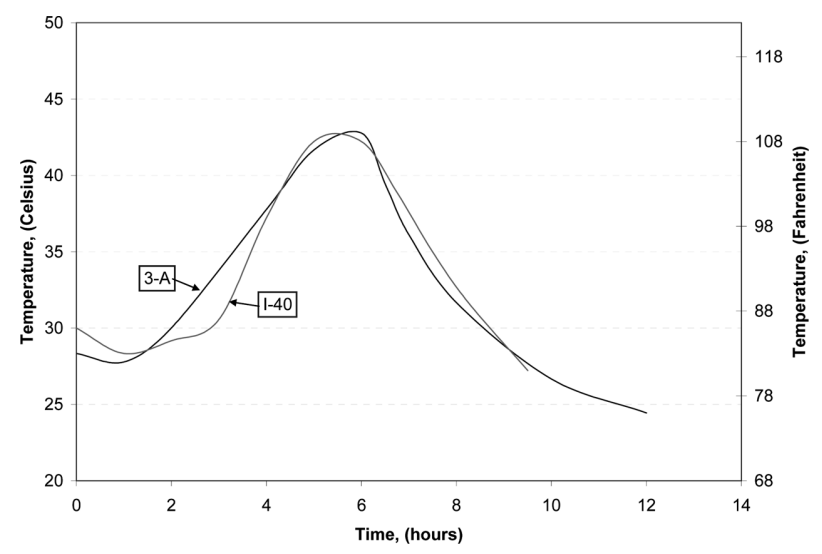

Fig. 9 Temperature of concrete (Mix 3-A and I-40).

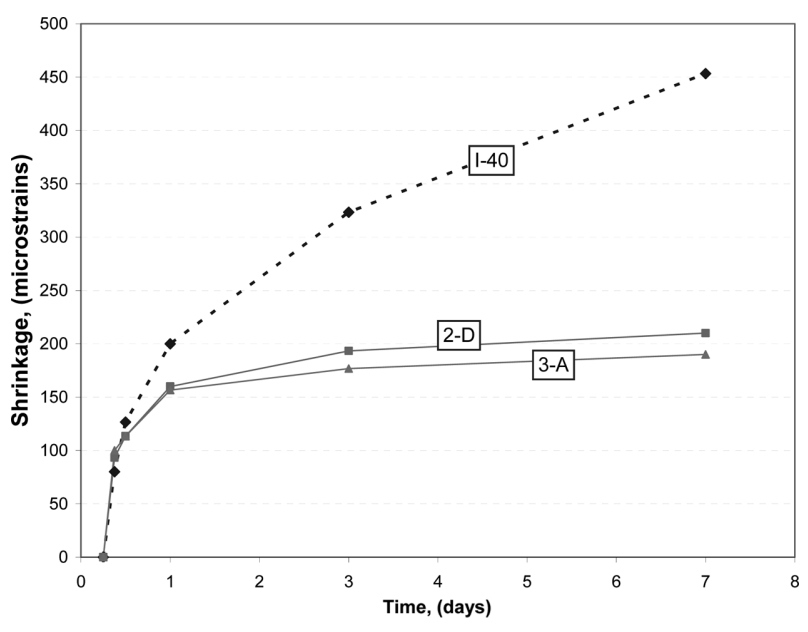

Fig. 10 Shrinkage (Mix 2-D, 3-A and I-40).

Figure 10 illustrates the difference in shrinkage between Mixes 2-D, 3-A and I-40. Mix 3-A exhibited the characteristic of low shrinkage. At 28 days, Mix 3-A had only 280 microstrains of shrinkage while the I-40 ODOT Mix had over 740 microstrains of shrinkage. Mix 3 met all of the requirements for ODOT Class A concrete. The slump loss with time shown in Fig. 1 illustrates how this mix stays workable longer if mechanical energy is imparted to the material. It was found that a relatively un-roddable cylinder could still be worked if it was tapped sharply (i.e. vibrated). This vibration would tend to "liquefy" the concrete if its initial set had not yet occurred.

\section{Test program - Type I portland cement}

\subsection{Experimental program}

A Type I cement testing program was implemented to achieve three objectives: (1) to find a replacement material for the Type III cement which became extremely hard to find in Oklahoma, (2) to identify materials and procedures that can be reliably employed to patch and repair Portland cement concrete for roadway and bridge applications, and (3) to evaluate and define the material properties of the most promising materials. Two groups of tests were run to achieve these objectives. All of the materials considered were subjected to the primary objective tests. The materials that exhibited the most promising performance in the initial tests were subjected to the secondary objective tests. Testing procedure for the Type I cement was similar to that of the Type III cement, which is detailed in the preceding section.

The criteria that were used in this research to evaluate the different mix designs were based upon the criteria used to develop the batch materials deemed successful by ODOT as defined in the Type III testing program outlined previously. These criteria are based primarily upon the compressive strength, shrinkage and initial slump of the concrete mix as follows:
- Compressive strength $\geq 20.7 \mathrm{MPa}(3,000$ psi)@6hours
- Unrestrained shrinkage $\leq 500$ microstrains@28 days
- Initial slump 25 to $76 \mathrm{~mm}$ ( 1 to 3 inches)

\subsection{Testing and discussion of test results}

Early age strength is of importance in patch mixes, and meeting the minimum compressive strength is an ODOT requirement for 
opening a patched road for traffic. Because of the high degree of repeatability of ASTM C $39^{12}$ compressive strength testing, compressive strength was used to evaluate and reduce the test matrix to size. Five different cement contents, from 500 to 900 pounds per cubic yard (pcy), were tested for early strength gain. Initially, $356 \mathrm{~kg} / \mathrm{m}^{3}$ (600 pcy) and $475 \mathrm{~kg} / \mathrm{m}^{3}$ (800 pcy) showed the most promise. However, as research continued it became apparent that $356 \mathrm{~kg} / \mathrm{m}^{3}$ (600 pcy) was not going to produce the required early strength; therefore, it was abandoned and $534 \mathrm{~kg} / \mathrm{m}^{3}$ (900 pcy) was tested further.

Another important variable that has a significant impact on the strength of Portland cement concrete is the water-to-cement (w/c) ratio. In general, the lower the $\mathrm{w} / \mathrm{c}$ is, the higher the strength. The theoretical minimum for the $\mathrm{w} / \mathrm{c}$ is somewhere around $0.24 \sim 0.27$ (Mindess and Young ${ }^{5}$ ). At early age, it was not known what direct impact the w/c ratio would have. This study was conducted without the use of accelerators or air entrainment admixtures. The batch mixes tested for $475 \mathrm{~kg} / \mathrm{m}^{3}$ (800 pcy) indicated that the optimum $w / c$ lay around 0.30 . There was a decrease in strength when the w/c was reduced below 0.30 , which can be attributed to the very poor workability of the mix. The combined effect of the accelerator and $0.27 \mathrm{w} / \mathrm{c}$ made it very hard to achieve proper consolidation. This poor consolidation created large voids in the test specimens and negatively affected the strength. It is the researchers' opinion that a patch mix with a $0.27 \mathrm{w} / \mathrm{c}$ would be impossible to batch in the field with the superplasticizers used in this research program.

The amount of the accelerator was also examined. These dosages varied from 12.6 to $44.2 \mathrm{~L} / \mathrm{m}^{3}$ (326 to 1,141 ounces/cubic yard) for the $475 \mathrm{~kg} / \mathrm{m}^{3}$ ( $800 \mathrm{pcy}$ ) cement mix. The compressive strength gain curve for the $475 \mathrm{~kg} / \mathrm{m}^{3}$ (800 pcy) cement mix is shown in Fig. 11. The optimal dosage rate for early age strength gain at $475 \mathrm{~kg} / \mathrm{m}^{3}$ (800 pcy) appeared to be $37.8 \mathrm{~L} / \mathrm{m}^{3}$ (978 oz/cy). At $44.2 \mathrm{~L} / \mathrm{m}^{3}$ (1,141 oz/cy), the mix became so harsh that proper consolidation was not achieved. This is believed to be the reason for the sharp reduction in strength that occurred.

To confirm this optimal dosage rate, one additional batch was mixed with $534 \mathrm{~kg} / \mathrm{m}^{3}$ (900 pcy) of cement and an accelerator dosage rate of $37.8 \mathrm{~L} / \mathrm{m}^{3}$ (978 oz/cy), the optimum dosage of the $475 \mathrm{~kg} / \mathrm{m}^{3}$ (800 pcy) cement mix. This study was conducted without the use of air entrainment admixtures, which resulted in a favorable increase in the early strength gain of the $534 \mathrm{~kg} / \mathrm{m}^{3}(900$

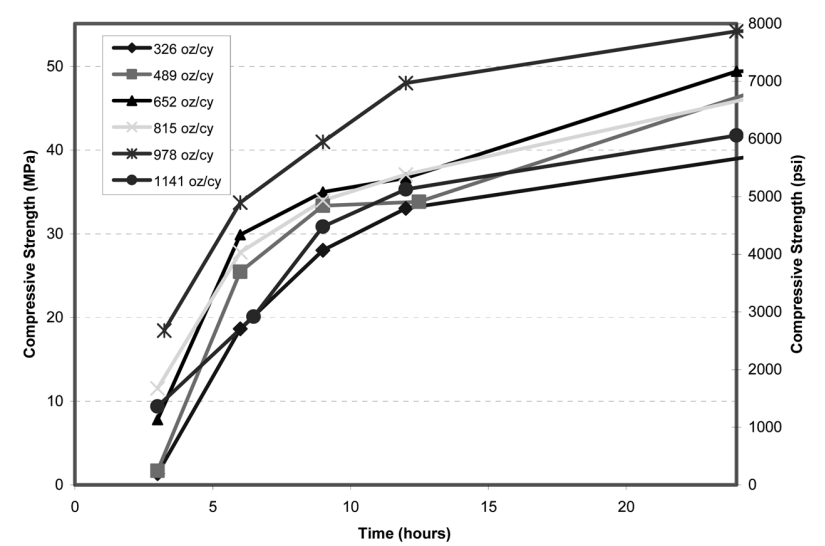

Fig. 11 Early age effect of accelerator dosage with 800 pcy Type I cement.

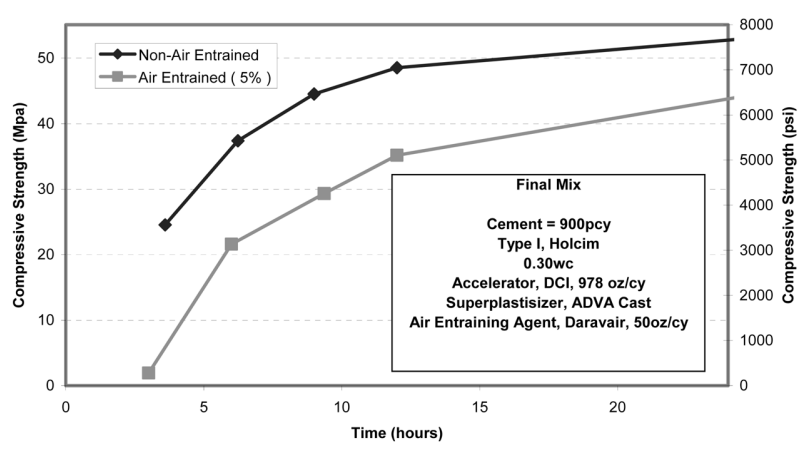

Fig. 12 Effect of air entrainment on early age strength (Type I cement final mix).

pcy) mix. The substantial early strength gain at the dosage rate of $37.8 \mathrm{~L} / \mathrm{m}^{3}$ (978 oz/cy) is of great advantage, although the higher cement content may increase shrinkage slightly.

Finally, the impact of the addition of air entrainment to the concrete strength was investigated. The concrete had to be entrained with air, per ODOT requirements, to be able to withstand freezethaw. Typically, the addition of air is known to cause a significant reduction in strength. ${ }^{5}$ Although this was true in early strength gain for the case tested, as shown in Fig. 12, adding air entrainment dropped the strength of the mix to just above $20.7 \mathrm{MPa}$ $(3,000 \mathrm{psi})$ at six hours, which is the target strength for a roadway to be able to open. Moreover, the addition of the air entrainment did not appear to affect the final strength. This was a critical breakthrough in the development of a successful patch mix. Also, the addition of the air entrainment did not appear to affect the final strength.

In addition of the strength, the shrinkage effects resulting from the addition of air were measured and are plotted in Fig. 13. Entraining air into the mix significantly increased the shrinkage. The added voids in the concrete might have reduced the amount of aggregate restraint against shrinkage. A more complete study is required to understand this phenomenon. Nonetheless, overall, the addition of air moderately increased shrinkage at 28 days to a value just below the benchmark of 500 microstrains.

\subsection{Final type I portland cement mix}

The final Type I Portland cement mix developed during the course of this research was made up of the ingredients and propor-

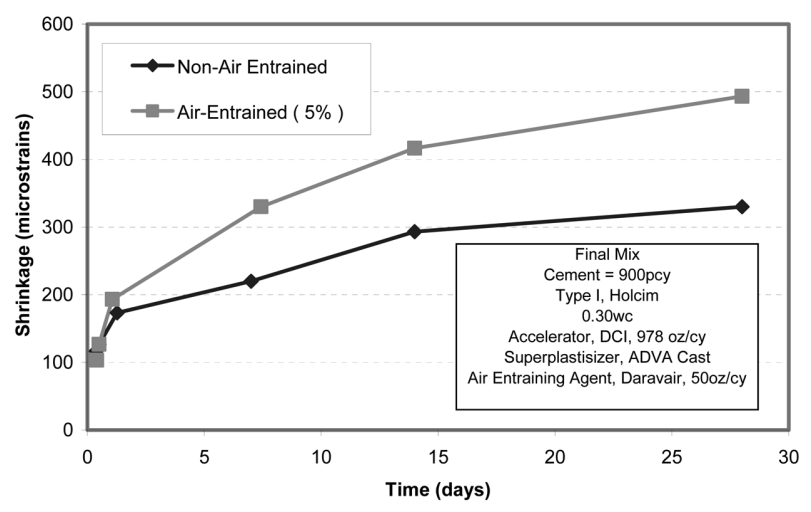

Fig. 13 Effect of air entrainment on shrinkage (Type I cement final mix). 
Table 5 Final mix proportions (with Type I Portland cement).

\begin{tabular}{c|c}
\hline Ingredient & Amount for $1 \mathrm{~m}^{3}\left(1 \mathrm{yd}^{3}\right)$ \\
\hline Type I, holcium cement & $534 \mathrm{~kg}(900.0 \mathrm{lb})$ \\
\hline \#67, coarse aggregate & $1061 \mathrm{~kg}(1787.8 \mathrm{lb})$ \\
\hline River sand, fine aggregate & $445 \mathrm{~kg}(750.5 \mathrm{lb})$ \\
\hline Water & $128 \mathrm{~kg}(216.51 \mathrm{lb})$ \\
\hline Daravair (AEA) & $1.93 \mathrm{~L}(50.0 \mathrm{oz})$ \\
\hline ADVA cast (HRWR) & $2.27 \mathrm{~L}(58.7 \mathrm{oz})$ \\
\hline DCI (accelerator) & $37.8 \mathrm{~L}(978.2 \mathrm{oz})$ \\
\hline
\end{tabular}

Note: Water amount assumes aggregate is at SSD condition.

tions found in Table 5. This mix was not batched according to the typical mixing procedure of $3 \mathrm{~min}$. mixing, $3 \mathrm{~min}$. rest, $2 \mathrm{~min}$. mixing. It was mixed until the air entrainment was between $5 \%$ and $6 \%$. This is the only time during this study when the typical mixing procedure was modified. The mix shown in Table 5 had much larger cement content per unit than the Type III mix design described in this paper. This increased cement content was necessary to achieve ODOT's minimum strength requirement of 20.7 $\mathrm{MPa}(3,000 \mathrm{psi})$ at 6 hours. Strength requirements must be met before the patched lane can be reopened to traffic, and this was the primary objective of the project.

Being able to entrain the right amount of air was rather hard and required some special procedures. This mix was a very hot (exothermic) mix which negatively affected the ability to entrain air. In order for the air entraining admixture (AEA) to work effectively, the batch temperature needed to be reduced. Therefore, about half of the water in the mix was ice. The AEA was also added to the water and mixed before adding it to the rest of the aggregate and cement.

The AEA was also sensitive to mixing time. If a batch is mixed for an extended amount of time, the air content can drastically increase and then slowly decrease. Obtaining the right air content takes significant operator skill and knowledge. Consideration may be given to not entraining air, if freeze-thaw tests indicate that it is not necessary.

\section{Summary and conclusions}

An experimental study to develop very early strength mix designs with low shrinkage properties was conducted using Type I and III Portland cements. Based on the test results, the following conclusions were drawn:

1) A Very Early Strength (VES) concrete with minimal Type III cement content is possible.

2) This VES mix tested in this study will have greatly improved shrinkage characteristics. For this tested VES mix, decreasing the Type III cement content does decrease the shrinkage but negatively impacts the early age strength gain required.

3) The finishing and workability characteristics of the Type III mix are superior to most mixes presently used.

4) A patch mix using any of the Portland Type I cements commercially available in Oklahoma is possible, but increasing the Type I cement content is necessary for early age strength gain.

5) Adding air entrainment will increase shrinkage in the Type I accelerated mixes.

\section{Acknowledgments}

The work presented in this paper was funded by the Oklahoma Department of Transportation, and the testing was conducted in the Donald G. Fears Structural Engineering Laboratory at the University of Oklahoma. The views expressed are those of authors, and do not necessarily represent those of the sponsor.

\section{References}

1. Zia, P., Leming, M., Ahmad, S., Schemmel, J., and Elliot, R., "Production of High Performance Concrete," Mechanical Behavior of High Performance Concretes, Vol. 2, Report SHRPC-362, Strategic Highway Research Program, National Research Council, 1993.

2. Cusson, D. and Mailvaganam, N., "Durability of Repair Materials," Concrete International, American Concrete Institute, Vol. 18, No. 3, 1996, pp. 34 48.

3. Emmons, P. H., Vaysburd, A., and McDold, J., "A Rational Approach to Durable Concrete Repairs," Concrete International, American Concrete Institute, Vol. 15, No. 9, 1993, pp. 40 45.

4. Emmons, P. H., Vaysburd, A., and McDold, J., "Concrete Repair in the Future Turn of the Century - Any Problems?," Concrete International, American Concrete Institute, Vol. 16, No. 3, 1994, pp. 42 49.

5. Mindess, S. and Young, J. F., Concrete, Prentice-Hall, Inc., New Jersey, 1981, 671 pp.

6. Balogh, A., "New Admixture Combats Concrete Shrinkage," Concrete Construction, Vol. 41, No. 7, 1996, pp. 546 551.

7. Zakka, Z. A., and Carrasquillo, R. L., Effects of High-Range Water Reducers on the Properties of Fresh and Hardened Concrete, Research Report 1117-3F, Center for Transportation Research, University of Texas at Austin, Oct. 1989.

8. ASTM C 33-03, Standard Specification for Concrete Aggregates, ASTM International, West Conshohocken, Pa., 2003, 11 pp.

9. ASTM C 494/C 494M-05a, Standard Specification for Chemical Admixtures for Concrete, ASTM International, West Conshohocken, Pa., 2005, 10 pp.

10. ASTM C 260-01, Standard Specification for Air-Entraining Admixtures for Concrete, ASTM International, West Conshohocken, Pa., 2001, 3 pp.

11. ASTM C 490-04, Standard Practice for Use of Apparatus for the Determination of Length Change of Hardened Cement Paste, Mortar, and Concrete, ASTM International, West Conshohocken, Pa., 2004, 5 pp.

12. ASTM C 39/C 39M-04a, Standard Test Method for Compressive Strength of Cylindrical Concrete Specimens, ASTM International, West Conshohocken, Pa., 2004, 7 pp.

13. ASTM C 882-99, Standard Test Method for Bond Strength of Epoxy-Resin Systems Used with Concrete by Slant Shear, ASTM International, West Conshohocken, Pa., 1999, 4 pp.

14. ASTM C 469-94/ C 469-94e1, Standard Test Method for Static Modulus of Elasticity and Poisson's Ratio of Concrete in Compression, ASTM International, West Conshohocken, Pa., 1994, 4 pp.

15. ASTM C 1202-05, Standard Test Method for Electrical Indication of Concrete's Ability to Resist Chloride Ion Penetration, ASTM International, West Conshohocken, Pa., 2005, 6 pp.

16. ASTM C 403/C 403M-06, Standard Test Method for Time of Setting of Concrete Mixtures by Penetration Resistance, ASTM International, West Conshohocken, Pa., 2006, 7 pp. 